\title{
David Oliver: Rosy retrospection, nostalgia, and the NHS
}

\section{David Oliver consultant in geriatrics and acute general medicine}

Berkshire

The NHS turned 70 this year and faces numerous challenges. This has prompted many to debate current and future healthcare services and to look back at the NHS's journey since 1948.

A fond nostalgia has its place. But one step beyond is "rosy retrospection"- - a psychological phenomenon of cognitive bias whereby people simplify or exaggerate to judge the past more favourably than the present. ${ }^{12}$ Excessively positive retrospective narratives sometimes come from people who weren't there the first time around but speak confidently about imagined golden eras. I've doubtless donned rose tinted lenses myself sometimes but, as I enter my 30th year as an NHS doctor, I'd prefer to avoid them when discussing present and future healthcare.

Before the European Union Working Time Directive ${ }^{3}$ placed restrictions on junior doctors' working hours some brutal on-call rotas were commonplace ( 1 in 2, 1 in 3, or 1 in 4), including continuous 80 hour weekend and 36 hour weekday blocks, with no sleep guaranteed. ${ }^{4}$ Tired doctors put patients' and their own health at risk. ${ }^{5}$ On the other hand, the exhaustion came with free (if basic) onsite accommodation, camaraderie, peer support, and the continuity of a firm structure, and we quickly gained vast amounts of hands-on experience. The loss of those hours is still sometimes lamented in surgical specialties, ${ }^{67}$ but-with minimal induction, far less senior supervision, a "see one, do one, teach one" approach to many quite risky invasive procedures and operations, and far less scrutiny on safety and preventable harm-the effect of that rosy filter starts to diminish.

Care was arguably far more regimented, institutional, and paternalistic - and patients more deferential

The historical switch, in Modernising Medical Careers, ${ }^{8}$ to run through higher specialty medical training from previously more meandering routes has also attracted much adverse comment, as has the botched introduction of the Medical Training Application Service ${ }^{9}$ in 2007 or more recent findings that junior doctors often feel rushed or pressurised to decide on a specialty stem too early in their career. ${ }^{1011}$

On the other hand, back in the day many senior registrars, long qualified to become consultants, waited endlessly for consultant posts to become vacant. And not for nothing did the Department of Health report that led to Modernising Medical Careers call senior house officers "the lost tribe," ${ }^{2}$ as so many doctors were stuck or drifting at that grade and sometimes trying to enter a specialty they weren't suited to or, realistically, able to enter. ${ }^{13}$ Nor did we have today's transparency and scrutiny around preferential selection based on sex, race, or patronage.

Another example of la vie en rose is those yearnings in sections of the mainstream media and letters pages for golden ages of nursing — where A levels, let alone degrees, weren't required, and where fondly remembered, fearsome matrons ruled wards with a rod of iron, insisting on shipshape ward cleanliness, hierarchies, and militaristic rules. Yet patient case mix and healthcare were far less acute and complex; pressure and throughput on beds was lower; and a far more limited range of interventions was available for nurses to carry out, let alone as independent advanced practitioners or prescribers. Care was arguably far more regimented, institutional, and paternalistic — and patients more deferential. Besides, the research evidence tells us that graduate nurses improve patient outcomes. $^{14}$

A rosy retrospective makes us forget just how far healthcare has come in terms of evidence, interventions, safety, and outcomes. Clinical staff may formerly have had more professional autonomy, a greater sense of belonging, less managerial and political interference, and a far lower burden of documentation and regulatory or public scrutiny; but some of that burden came about precisely because, when the professionals ran their own show, not everything was rosy.

Competing interests: See www.bmj.com/about-bmj/freelance-contributors/davidoliver.

Provenance and peer review: Commissioned; not externally peer reviewed.

Neese B. Rosy retrospection: a look at the psychological phenomenon. Southeastern University. 23 Feb 2016. https://online.seu.edu/rosy-retrospection-psychologicalphenomenon/.

2 Mitchell TR, Thompson L, Peterson E, Cronk R. Temporal adjustments in the evaluation of events: the "rosy view".J Exp Soc Psychol 1997;33:421-48. https://www.sciencedirect. 
com/science/article/pii/S0022103197913330.

10.1006/jesp.1997.133310.1006/jesp.1997.1333 9247371

3 Lambert TW, Smith F, Goldacre MJ. The impact of the European Working Time Directive 10 years on: views of the UK medical graduates of 2002 surveyed in 2013-2014. JRSM Open 2016;7:2054270416632703. https://www.ncbi.nlm.nih.gov/pmc/articles/PMC4776251/ .10.1177/2054270416632703 26981257

4 White C. Was there ever a golden age for junior doctors?BMJ 2016;354:i3662 $10.1136 /$ bmj. 1366227383244

5 Kamau C. Safe working hours protect doctors from sleep deprivation [electronic response to Gulland A, "Limits on working hours may be relaxed after Brexit, warns employment expert"]. BMJ 2017. https://www.bmj.com/content/359/bmj.j4547/rr.

6 Luther A, Hart C, Mann C, Kang P. The European Working Time Regulations: time for change? RCS Bulletin 2014;96:86-8. https://publishing.rcseng.ac.uk/doi/full/10.1308/ 003588414 X13814021678079.

7 Chapman SJ. European Working Time Directive: more harm than good for surgical trainees [electronic response to Hartle A and Gibb S, "Head to Head: Can doctors be trained in a 48 hour working week?"] BMJ 2014. https://www.bmj.com/content/349/bmj.g7323/rr/ 826511 .

8 Seah R. Integrated specialty training. BMJ 2009;338:b2910.1136/bmj.b29.
9 Elton C. The ongoing fallout from MTAS. BMJ 2013;346:f220610.1136/bmj.f2206 .

10 Smith SE, Tallentire VR, Pope LM, Laidlaw AH, Morrison J. Foundation Year 2 doctors' reasons for leaving UK medicine: an in-depth analysis of decision-making using semistructured interviews. BMJ Open 2018;8:e019456. https://bmjopen.bmj.com/content/ bmjopen/8/3/e019456.full.pdf. 10.1136/bmjopen-2017-019456 29500208

11 BMA. BMA research reveals reasons behind large numbers of junior doctors taking breaks in training. 1 March 2018. https://www.bma.org.uk/news/media-centre/press-releases/ 2018/march/bma-research-reveals-reasons-behind-large-numbers-of-junior-doctors-takingbreaks-in-training

12 Bonner J. The MMC story. BMJ 2006;333:s20310.1136/bmj.333.7579.s203-a .

13 Sritharan K. SHOs: the lost tribe?BMJ 2005;331:s9010.1136/bmj.331.7514.s90.

14 Degree educated nurses can reduce hospital deaths. King's College, London. 28 Feb 2014. www.kcl.ac.uk/nursing/newsevents/news/2014/degree-educated-nurses-can-reducehospital-deaths.aspx.

Published by the BMJ Publishing Group Limited. For permission to use (where not already granted under a licence) please go to http://group.bmj.com/group/rights-licensing/ permissions 